\title{
Student's Knowledge, Attitudes, and Practices Related to Cardiopulmonary Resuscitation at Qassim University, Saudi Arabia
}

\author{
Ali Mansour ${ }^{1,2}$, Ahmad H. Alsager ${ }^{3}$, Abdulrahman Alasqah ${ }^{3}$, Abdullah S. Altamimi ${ }^{3}$, Abdulaziz \\ Alsuhaibani $^{3}$, Ahmed A. Aljabr ${ }^{3}$, Abdullah I. AlDughaim ${ }^{3}$ \\ 1. Family \& Community Medicine, Unaizah College of Medicine, Qassim University, Unaizah, SAU 2. Community \\ Medicine, Damietta Faculty of Medicine, Al-Azhar University, Damietta, EGY 3. Medicine, Unaizah College of Medicine, \\ Qassim University, Unaizah, SAU
}

Corresponding author: Abdulrahman Alasqah, al3mer95@gmail.com

\section{Abstract \\ Background}

Cardiopulmonary resuscitation (CPR) is a lifesaving technique that is vital to deal with in many emergencies. Early interference with the cardiopulmonary resuscitation technique is really important for the survival of the patient. This study assesses the level of knowledge, attitudes, and practices regarding CPR among Qassim University students.

\section{Materials and methods}

A cross-sectional study was conducted at Qassim University. The sample was university students. The colleges were chosen by a simple random technique. Data were collected using a pretested, semi-structured questionnaire for knowledge, attitudes, and practices related to CPR. The data were analyzed using Statistical Package for the Social Sciences (SPSS; IBM Corporation, Armonk, NY).

\section{Results}

The total sample size of the participating students was 1148 , of which $589(51.3 \%)$ were female and the remaining were male $(559,48.7 \%)$. The common age was between 20 and 23 years old and most were from non-medical colleges (54.1\%); the remaining (45.9\%) were from medical colleges. The majority of female students (45.7\%) in medical colleges knew the right location for chest compression better than the males, with a significant difference $(\mathrm{p}<0.05)$. No significant difference existed between males and females $(\mathrm{p}>0.05)$ regarding most CPR practices. On the other hand, there was a significant increase among medical students as compared to non-medical students $(p<0.05)$ regarding most knowledge, attitudes, and practice items of CPR.

Received 10/22/2019

Review began 11/01/2019 Review ended 11/15/2019 Published 11/16/2019

(๑) Copyright 2019 Mansour et al. This is an open access article distributed under the terms of the Creative Commons Attribution License CC-BY 3.0., which permits unrestricted use, distribution, and reproduction in any medium, provided the original author and source are credited.

\section{Conclusion}

Based on our study, the knowledge, attitudes, and practices of Qassim University students toward CPR are insufficient and need to be improved. Also, medical students are better than non-medical students at CPR, so we recommend that the incorporation of a Basic Life Support (BLS) course, including CPR learning procedures in the university curriculum, with regular reassessments, would increase the knowledge and application of CPR skills among students for saving people's life.

Categories: Emergency Medicine, Medical Education, Epidemiology/Public Health

Keywords: cpr, knowledge, attitudes, practices, students, qassim

\section{Introduction}

Cardiopulmonary resuscitation (CPR) is the first prompt and initial action provided to a cardiac arrest patient. In the best possible condition, this efficient action is taken to keep the patient alive until emergency medical services and treatment can be obtained. Early intervention with the CPR technique is crucially important for the survival of the patient. The more effective and efficient the caregiver or 'bystander' is, the better the results will be on the ground [1].

Cardiac arrest is the sudden stopping of the pumping function of the heart and, therefore, the need for CPR for people whose hearts or breathing has stopped. The mechanism of CPR is performed by doing rescue breathing and chest compressions. It is known that about $75 \%$ of cardiac arrests happen at home. Therefore, the need for CPR by bystanders emerges to raise the chances of survival of the patient. Studies have shown that immediate and successful CPR may raise the chance of survival from double to triple [2-3]. 
Sudden cardiac death (SCD) is a common and devastating event, often occurring in the early age of one's life. SCD is considered to be the most common and leading cause of death outside the hospital worldwide. In the USA, according to one study, the incidence of SCD was found to be 300,000-450,000 per year.

Researchers also found that the peaks of SCD are bimodal, occurring at the age of infancy and after the age of 45. In the USA, almost $50 \%$ of adults who suffer from SCD were found to have coronary heart disease (CHD). One study was done on New Zealand's high-school students to assess the level of the knowledge of the students towards CPR. The students showed a poor understanding of resuscitation; only $22 \%$ of them knew what CPR means [4-5].

According to one study on King Saud University students in Riyadh, Saudi Arabia, it found that 31\% of the students had no idea about CPR, 85\% felt that their knowledge was weak, and $10 \%$ believed that their knowledge was good [6].

According to our search, no study was done regarding the knowledge and attitudes towards CPR that has included all Qassim University students in the Qassim region of Saudi Arabia. So, our study was conducted to assess the level of knowledge, attitudes, and practices regarding cardiopulmonary resuscitation among all Qassim University students.

\section{Materials And Methods \\ Study design}

A cross-sectional study was conducted during the academic year 2018-2019.

\section{Study setting}

Students of Qassim University, Qassim region, Saudi Arabia

\section{Sample size}

The study participants are samples from the students of Qassim University. The colleges were chosen by the simple random technique. The sample size was calculated by using a specific sample size equation for a cross-sectional study: $\mathrm{n}=\mathrm{Z}^{2}(1-\alpha) \mathrm{p}(1-\mathrm{p}) / \mathrm{d}^{2}$ The total sample size was 1148 students from seven colleges.

\section{Sampling technique}

The simple random technique

\section{Data collection methods}

Data were collected using a pretested, semi-structured questionnaire. The questionnaire was devised from the literature and formal discussions with experts. It is in the Arabic language, and it consisted of 37 items pertaining to the demographic profile, knowledge, attitudes, and practices towards CPR among university students at Qassim University, Saudi Arabia.

\section{Pilot study}

The pilot study was done on 20 students (10 male and 10 female) before starting our study, to test the validity of our questionnaire and to estimate the timing needed for each participant to complete the questionnaire.

\section{Data analysis plan}

The data were entered, organized, tabulated, and analyzed by using Statistical Package for the Social Sciences (SPSS) version 24 (IBM Corporation, Armonk, NY) and for the purpose of data analysis and presentation. Qualitative data were expressed as frequency and percent. Chi-square (x2) was used to assess the relationship between the qualitative variables and the Students t-test was used for comparing the quantitative variables with the significance level set at a $p$-value of $<0.05$.

\section{Results}

\section{Characteristics of participant students}

The total sample size of the participating students was 1148 , of which 589 (51.3\%) were female and the remaining were male $(559 ; 48.7 \%)$. The common age for them was between 20 and 23 years old. Most of them were from non-medical colleges (54.1\%) and the remaining (45.9\%) from medical colleges. Also, the majority of students were in the third and fourth academic years ( $28.7 \%$ and $22.4 \%$, respectively). The family income of most students was more than 10000 SR ( $\approx 2666$ USD) per month (Table 1$)$. 


\section{Cureus}

\begin{tabular}{|c|c|c|c|}
\hline \multicolumn{2}{|l|}{ Demographic characteristics } & Frequency $\mathrm{N}=1148$ & Percent \\
\hline \multirow{2}{*}{ Gender } & Male & 559 & 48.7 \\
\hline & Female & 589 & 51.3 \\
\hline \multirow{3}{*}{ Age } & $<20$ years & 105 & 9.1 \\
\hline & 20-23 years & 898 & 78.2 \\
\hline & $>23$ years & 145 & 12.6 \\
\hline \multirow{7}{*}{ Colleges } & Unaizah College of Medicine & 294 & 25.6 \\
\hline & Unaizah College of Pharmacy & 156 & 13.6 \\
\hline & Unaizah College of Sciences and Arts & 229 & 19.9 \\
\hline & College of Sharia & 105 & 9.1 \\
\hline & College of Engineering & 78 & 6.8 \\
\hline & College of Applied Health Sciences in Al Rass & 79 & 6.9 \\
\hline & College of Sciences and Arts in Abadyaa & 207 & 18.0 \\
\hline \multirow{5}{*}{ Academic Years } & $1^{\text {st }}$ year & 126 & 11 \\
\hline & $2^{\text {nd }}$ year & 212 & 18.5 \\
\hline & $3^{\text {rd }}$ year & 329 & 28.7 \\
\hline & $4^{\text {th }}$ year & 257 & 22.4 \\
\hline & $5^{\text {th }}$ year & 224 & 19.5 \\
\hline \multirow{2}{*}{ Family Income } & $\leq 10000 \mathrm{SR}$ & 403 & 35.1 \\
\hline & $>10000 \mathrm{SR}$ & 745 & 64.9 \\
\hline \multirow{2}{*}{ Medical vs. Non- Medical colleges } & Medical college students & 527 & 45.9 \\
\hline & Non-medical college students & 621 & 54.1 \\
\hline Total & & 1148 & 100 \\
\hline
\end{tabular}

TABLE 1: Demographic characteristics of participating students

\section{Students' knowledge of CPR}

The majority of students knew the emergency telephone number of Saudi Arabia Red Crescent (55.1\%) and only (35.6\%) of them knew the abbreviation of BLS. In addition, $43.0 \%$ of students mentioned that the survival rate in out-of-hospital cardiac arrest if CPR is performed correctly is $70 \%$. Most of them (44.1\%) revealed that the mid-chest is the location of chest compression application and $40.8 \%$ of them stated that $2 \frac{1}{2}$ inches to 3 inches is the proper chest compression depth in CPR for adult persons. Only $24.2 \%$ of students mentioned that the chest compression rate for adults and children is $100 / \mathrm{min}$. Also, $36.3 \%$ of them revealed that the chest compression rate in CPR if you are the only one doing it is 5:1 (Table 2). 


\section{Cureus}

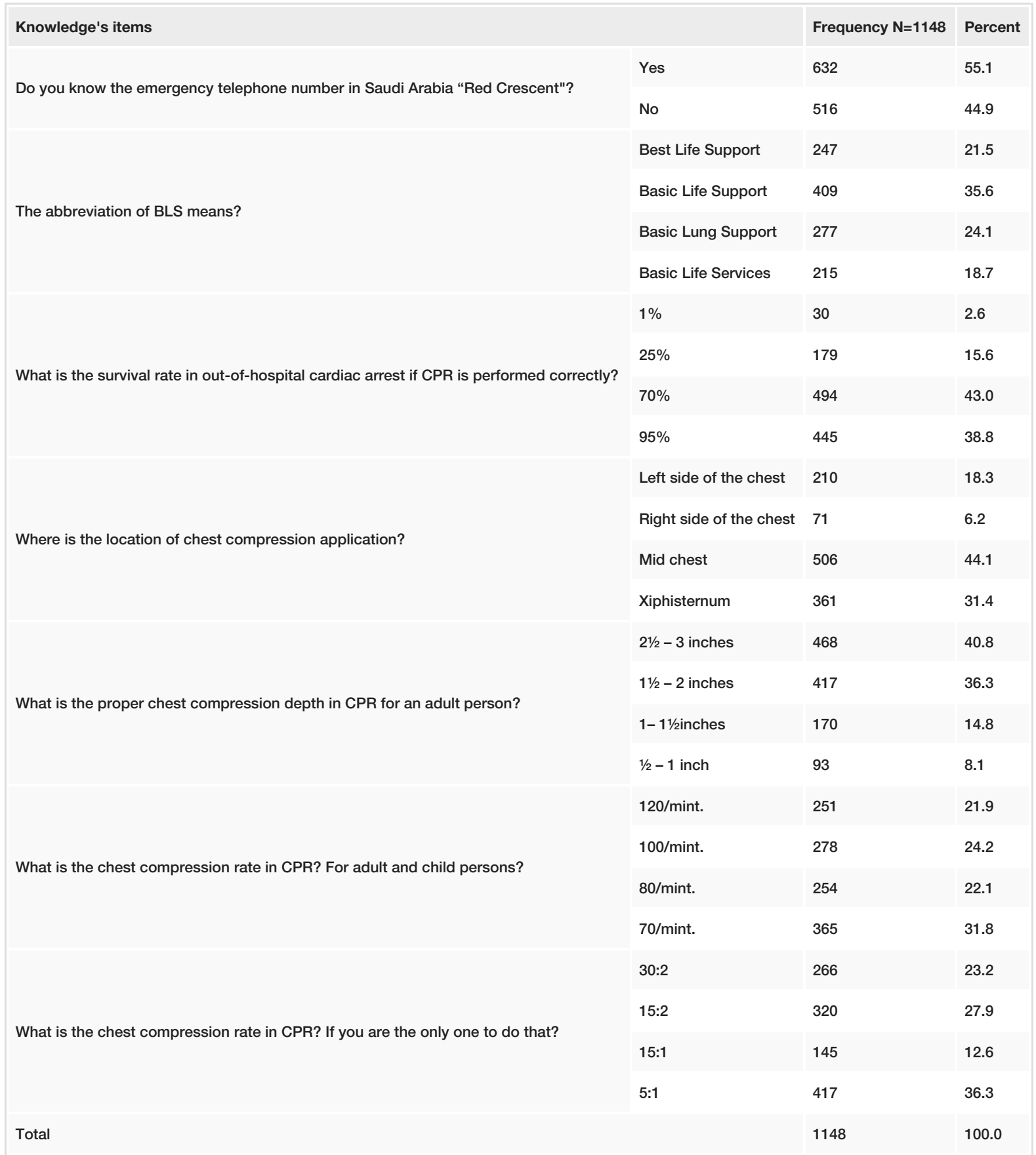

TABLE 2: Knowledge of Qassim University students regarding cardiopulmonary resuscitation (CPR)

\section{Attitudes of students towards CPR}

About $55.5 \%$ of students think that a CPR training course is mandatory for all students as a graduation requirement, and about $40.1 \%$ of them stated that the best method to increase public awareness of the importance of CPR is to inform people about the currently available training courses. The majority of students strongly agree and also agree about the benefits of CPR training courses to public life saving $(66.9 \%$ and $24.9 \%$, respectively). Also, most students (77.5\%) did not have a CPR training course, and the majority of them (82.5\%) wanted to learn CPR (Table 3). 


\section{Cureus}

\begin{tabular}{|c|c|c|c|}
\hline \multicolumn{2}{|l|}{ Attitudes items } & $\begin{array}{l}\text { Frequency } \\
\mathrm{N}=1148\end{array}$ & Percen \\
\hline \multirow{4}{*}{ Do you think CPR training courses should be: } & Mandatory for all students (graduation & 635 & 55.3 \\
\hline & Mandatory for some majors & 205 & 17.9 \\
\hline & Optional & 269 & 23.4 \\
\hline & $\begin{array}{l}\text { Don't support the implementation of } \\
\text { training courses }\end{array}$ & 39 & 3.4 \\
\hline \multirow{5}{*}{$\begin{array}{l}\text { What is the BEST method-in your opinion- to increase public awareness } \\
\text { of the importance of CPR? }\end{array}$} & Increased publicity & 415 & 36.1 \\
\hline & $\begin{array}{l}\text { Inform people of the training courses } \\
\text { currently available }\end{array}$ & 466 & 40.6 \\
\hline & Free training courses & 176 & 15.3 \\
\hline & Increase the number of courses & 80 & 7.0 \\
\hline & Others & 11 & 1.0 \\
\hline \multirow{5}{*}{$\begin{array}{l}\text { Do you think CPR training is a benefit for students to save the lives of the } \\
\text { public? }\end{array}$} & Strongly agree & 768 & 66.9 \\
\hline & Agree & 286 & 24.9 \\
\hline & Neutral & 79 & 6.9 \\
\hline & Disagree & 8 & 0.7 \\
\hline & Strongly disagree & 7 & 0.6 \\
\hline \multirow{2}{*}{ Have you ever taken a CPR training course? } & Yes & 258 & 22.5 \\
\hline & No & 890 & 77.5 \\
\hline \multirow{3}{*}{ What encouraged you to take the course? } & $\begin{array}{l}\text { Work or graduation requirement } \\
\text { (Mandatory) }\end{array}$ & 57 & 5.0 \\
\hline & Personal benefit (Optional( & 179 & 15.6 \\
\hline & $\begin{array}{l}\text { Previous experience proved the } \\
\text { importance of CPR }\end{array}$ & 16 & 1.4 \\
\hline \multirow{2}{*}{ Do you want to learn CPR? } & Yes & 947 & 82.5 \\
\hline & No & 201 & 17.5 \\
\hline
\end{tabular}

TABLE 3: Attitudes of Qassim University students regarding cardiopulmonary resuscitation (CPR)

\section{Practices of students towards CPR}

With regards to the first response of students when they saw a comatose person, most of them stated that they looked for safety and open airways ( $46.4 \%$ and $35.5 \%$, respectively). The majority of students would activate emergency medical services (EMS) and start CPR if someone did not respond by moving or talking ( $47.9 \%$ and $35.8 \%$, respectively). Of the students, $34.4 \%$ would do mouth-mask ventilation and chest compression during CPR if they did not want to give artificial respiration. Of the participants, $37.9 \%$ will give abdominal thrusts to their friends if they were exposed to choking during eating. About $50 \%$ of students would do back blows and chest compression for five cycles and then open the mouth and remove the foreign body if they watched a child who suddenly started to choke. Of the participants, $42.9 \%$ would compress the abdomen to remove water for a drowned person. Of the students, $43.5 \%$ would take their colleagues to the nearest clinic if they were not able to speak and exposed to weakness in the right upper limb (Table 4). 


\section{Cureus}

\begin{tabular}{|c|c|c|c|}
\hline \multicolumn{2}{|l|}{ Practices items } & $\begin{array}{l}\text { Frequency } \\
\mathrm{N}=1148\end{array}$ & Percent \\
\hline \multirow{4}{*}{ If you see someone comatose, what is your first response? } & Open airway & 409 & 35.6 \\
\hline & Start chest compression & 163 & 14.2 \\
\hline & Look for safety & 533 & 46.4 \\
\hline & Give two breathings & 43 & 3.7 \\
\hline \multirow{4}{*}{$\begin{array}{l}\text { After making sure that someone does not respond to you even } \\
\text { after you try to move him and talk to him what to do }\end{array}$} & Start CPR & 411 & 35.8 \\
\hline & Activate EMS & 550 & 47.9 \\
\hline & Put him in the recovery position & 148 & 12.9 \\
\hline & Observe & 39 & 3.4 \\
\hline \multirow{4}{*}{$\begin{array}{l}\text { If you do not want to give artificial respiration by direct contact } \\
\text { with the mouth during CPR work, you can do the following: }\end{array}$} & Mouth-mask ventilation and chest compression & 399 & 34.4 \\
\hline & Chest compression only & 264 & 23.0 \\
\hline & Mask ventilation with chest compression & 194 & 16.9 \\
\hline & No CPR & 291 & 25.3 \\
\hline \multirow{4}{*}{$\begin{array}{l}\text { If you and your friend are eating at the canteen and suddenly your } \\
\text { friend is exposed to the symptoms of choking what to do }\end{array}$} & Give abdominal thrusts & 435 & 37.9 \\
\hline & Give chest compression & 243 & 21.2 \\
\hline & Confirm foreign body aspiration by talking to him & 154 & 13.4 \\
\hline & Give back blows & 316 & 27.5 \\
\hline \multirow{4}{*}{$\begin{array}{l}\text { You are watching a child who suddenly started to choke while } \\
\text { playing with him. I have made sure he is unable to cry or cough. } \\
\text { What is your first response? }\end{array}$} & Start CPR immediately & 122 & 10.6 \\
\hline & $\begin{array}{l}\text { Try to remove the suspected foreign body by blind } \\
\text { finger sweeping technique }\end{array}$ & 395 & 34.4 \\
\hline & $\begin{array}{l}\text { Back blows and chest compression of five cycles } \\
\text { each then open the mouth and remove foreign body } \\
\text { only when it is seen }\end{array}$ & 569 & 49.6 \\
\hline & Give water to the infant & 62 & 5.4 \\
\hline \multirow{4}{*}{$\begin{array}{l}\text { You see a person who does not respond after drowning in water. } \\
\text { After taking him out, he has breathing but does not respond. What } \\
\text { is the first step }\end{array}$} & CPR for two minutes and inform EMS & 297 & 25.9 \\
\hline & CPR for one minute and inform EMS & 239 & 20.8 \\
\hline & Compress the abdomen to remove the water & 492 & 42.9 \\
\hline & Keep him in the recovery position & 120 & 10.5 \\
\hline \multirow{4}{*}{$\begin{array}{l}\text { You noticed that your colleague was not able to speak and he } \\
\text { exposed to weakness in the right upper limb which one of the } \\
\text { following could be done }\end{array}$} & Offer him some drinks, probably hypoglycemia & 307 & 26.7 \\
\hline & Possibly stroke, get him to the nearest clinic & 499 & 43.5 \\
\hline & $\begin{array}{l}\text { Possibly stroke, he may require thrombolysis and } \\
\text { hence activate emergency medical services }\end{array}$ & 244 & 21.3 \\
\hline & May be due to sleep deprivation, make him sleep. & 98 & 8.5 \\
\hline
\end{tabular}

TABLE 4: Practices of Qassim University students regarding cardiopulmonary resuscitation (CPR)

EMS: emergency medical services

\section{Gender comparison for knowledge and attitudes}

Male students (58.3\%) knew the emergency telephone for Saudi Red Crescent more than females did, but the majority of female students (45.7\%) knew the right location for the application of chest compression more 


\section{Cureus}

than males did, with a significant difference between them $(\mathrm{p}<0.05)$ and $43.6 \%$ of female participants knew the proper depth of chest compression and the rate of CPR (23.9\%) more than males did, with no significant difference between them ( $p>0.05$ ). The majority of female students thought that the CPR training course is mandatory for all students as a graduation requirement (62.1\%), and they mentioned that the best method, in their opinion, to increase the awareness of the public regarding the CPR training course is to inform people of the training courses currently available (44.8\%). They also strongly agreed that the CPR training course is beneficial for students to save the lives of the public (73.7\%). And most of them (86.6\%) wanted to learn CPR more than males did, with a significant difference between them $(\mathrm{p}<0.05)$ (Table 5$)$.

\begin{tabular}{|c|c|c|c|c|}
\hline \multicolumn{2}{|l|}{ Variables } & $\begin{array}{l}\text { Male }(n= \\
559) \text { No \% }\end{array}$ & $\begin{array}{l}\text { Female } \\
(n=589) \text { No \% }\end{array}$ & $\begin{array}{l}\mathrm{P} \text { - } \\
\text { value }\end{array}$ \\
\hline \multirow{2}{*}{$\begin{array}{l}\text { Do you know the emergency telephone number in Saudi Arabia } \\
\text { "Red Crescent"? }\end{array}$} & Yes & $326(58.3 \%)$ & $306(52.0 \%)$ & \multirow{2}{*}{0.06} \\
\hline & No & $233(41.7 \%)$ & $283(48.0 \%)$ & \\
\hline \multirow{4}{*}{ The abbreviation of BLS. Means? } & Best Life Support & 111(19.9\%) & $136(23.1 \%)$ & \multirow{4}{*}{$\begin{array}{l}<0.001 \\
\mathrm{~S}^{\star}\end{array}$} \\
\hline & Basic Life Support & $177(31.7 \%)$ & $232(39.4 \%)$ & \\
\hline & Basic Lung Support & $136(24.3 \%)$ & $141(23.9 \%)$ & \\
\hline & Basic Life Services & $135(24.2 \%)$ & $80(13.6 \%)$ & \\
\hline \multirow{4}{*}{$\begin{array}{l}\text { What is the survival rate in out-of-hospital cardiac arrest if CPR is } \\
\text { performed correctly? }\end{array}$} & $1 \%$ & $19(3.4 \%)$ & $11(1.9 \%)$ & \multirow{4}{*}{$\begin{array}{l}<0.001 \\
S^{*}\end{array}$} \\
\hline & $25 \%$ & $111(199 \%)$ & $68(11.5 \%)$ & \\
\hline & $70 \%$ & $251(44.9 \%)$ & $243(41.3 \%)$ & \\
\hline & $95 \%$ & 178(31.8\%) & $267(45.3 \%)$ & \\
\hline \multirow{4}{*}{ Where is the location of the chest compression application? } & Left side of the chest & $96(17.2 \%)$ & $114(19.4 \%)$ & \multirow{4}{*}{$\begin{array}{l}0.016 \\
S^{*}\end{array}$} \\
\hline & Right side of the chest & $47(8.4 \%)$ & $24(4.1 \%)$ & \\
\hline & Mid chest & $237(42.4 \%)$ & $269(45.7 \%)$ & \\
\hline & Xiphisternum & 179(32.0\%) & $182(30.9 \%)$ & \\
\hline \multirow{4}{*}{$\begin{array}{l}\text { What is the proper chest compression depth in CPR For adult } \\
\text { person? }\end{array}$} & $2 \frac{1}{2}-3$ inches & $211(37.7 \%)$ & $257(43.6 \%)$ & \multirow{4}{*}{0.236} \\
\hline & 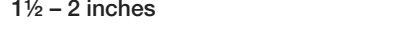 & 215(38.5\%) & $202(34.3 \%)$ & \\
\hline & $1-1 \frac{1}{2}$ inches & $87(15.6 \%)$ & $83(14.1 \%)$ & \\
\hline & $1 / 2-1$ inch & $46(8.2 \%)$ & $47(8.0 \%)$ & \\
\hline \multirow{4}{*}{$\begin{array}{l}\text { What is the chest compression rate in CPR for adults and } \\
\text { children? }\end{array}$} & 120/mint. & 114(20.4\%) & $137(23.3 \%)$ & \multirow{4}{*}{0.096} \\
\hline & 100/mint. & $137(24.5 \%)$ & $141(23.9 \%)$ & \\
\hline & 80/mint. & $140(25.0 \%)$ & 114(19.4\%) & \\
\hline & 70/mint. & $168(30.1 \%)$ & 197(33.4\%) & \\
\hline \multirow{4}{*}{$\begin{array}{l}\text { What is the chest compression rate in CPR., If you are the only } \\
\text { one to do that? }\end{array}$} & $30: 2$ & $134(24.0 \%)$ & 132(22.4\%) & \multirow{4}{*}{0.564} \\
\hline & $15: 2$ & $146(26.1 \%)$ & $174(29.5 \%)$ & \\
\hline & $15: 1$ & $69(12.3 \%)$ & $76(12.9 \%)$ & \\
\hline & $5: 1$ & $210(37.6 \%)$ & $207(35.1 \%)$ & \\
\hline \multirow{5}{*}{ Do you think CPR training courses should be: } & $\begin{array}{l}\text { Mandatory for all students } \\
\text { (graduation requirement) }\end{array}$ & $269(48.1 \%)$ & $366(62.1 \%)$ & \multirow{4}{*}{$\begin{array}{l}<0.001 \\
\mathrm{~S}^{*}\end{array}$} \\
\hline & Mandatory for some majors & $121(21.6 \%)$ & $84(14.3 \%)$ & \\
\hline & Optional & $145(25.9 \%)$ & $124(21.1 \%)$ & \\
\hline & $\begin{array}{l}\text { Don't support the implementation of } \\
\text { training courses }\end{array}$ & $24(4.3 \%)$ & $15(2.5 \%)$ & \\
\hline & Increased publicity & 229(41.0\%) & $186(31.6 \%)$ & \\
\hline
\end{tabular}




\section{Cureus}

What is the BEST method-in your opinion- to increase public awareness of the importance of CPR?

Do you think CPR training is beneficial for students to life-saving the public?

Have you ever taken a CPR training course?

What encouraged you to take the course?

Do you want to learn CPR?
Inform people of the training courses currently available

Free training courses

Increase the number of courses

Others

Strongly agree

Agree

Neutral

Disagree

Strongly disagree

Yes

No

Work or graduation requirement (Mandatory)

Personal benefit (Optional(

Previous experience proved the importance of CPR

Yes

No
$202(36.1 \%) \quad 264(44.8 \%)$

$100(17.0 \%) \quad S^{*}$

$28(4.8 \%)$

$0(0 \%) \quad 11(1.9 \%)$

$334(59.7 \%) \quad 434(73.7 \%)$

$159(24.4 \%) \quad 127(21.6 \%) \quad<0.001$

$55(9.8 \%) \quad 24(4.1 \%) \quad S^{*}$

$6(1.1 \%) \quad 2(0.3 \%)$

$5(0.9 \%) \quad 2(0.3 \%)$

110(19.7\%) $\quad 148(25.1 \%) \quad 0.027$

$449(80.3 \%) \quad 441(74.9 \%) \quad S$

$30(28.3 \%) \quad 27(18.5 \%)$

$67(63.2 \%) \quad 112(76.7 \%) \quad 0.064$

$9(8.5 \%) \quad 7(4.8 \%)$

$437(78.1 \%) \quad 510(86.6 \%)$

$<0.001$

$\mathrm{S} *$

\section{TABLE 5: Comparison between genders regarding the knowledge and attitudes of}

cardiopulmonary resuscitation (CPR)

*Significant

\section{Gender comparison for practices}

In regards the practice of $\mathrm{CPR}$, there is no significant difference between males and females $(p>0.05)$ in their first response if they saw a comatose person, giving abdominal thrusts if their friend was exposed to choking during eating, and compressing the abdomen to remove water if they saw a person drowning and not responding. But there is a significant increase among females rather than males $(\mathrm{p}<0.05)$ regarding the activation of EMS, starting CPR for someone not responding to moving and talking (48.0\%), implementing back blows and chest compression of five cycles followed by opening the mouth and removing the foreign body on watching a child who suddenly started to choke (50.3\%), and getting their colleagues to the nearest clinic if they were not able to speak and were exposed to weakness in the right upper limb (46.2\%) (Table 6).

\begin{tabular}{|c|c|c|c|c|}
\hline \multicolumn{2}{|l|}{ Variables } & $\begin{array}{l}\text { Male } \\
(n=559) \text { No } \\
\%\end{array}$ & $\begin{array}{l}\text { Female } \\
(n=589) \text { No } \\
\%\end{array}$ & $\begin{array}{l}P \\
\text { value }\end{array}$ \\
\hline \multirow{4}{*}{ If you see someone comatose, what is your first response? } & Open airway & 214(38.3\%) & 195(33.1\%) & \multirow{4}{*}{0.158} \\
\hline & Start chest compression & $81(14.5 \%)$ & $82(13.9 \%)$ & \\
\hline & Look for safety & $241(43.1 \%)$ & $292(49.6 \%)$ & \\
\hline & Give two breathings & $23(4.1 \%)$ & $20(3.4 \%)$ & \\
\hline \multirow{4}{*}{$\begin{array}{l}\text { After making sure that someone does not respond to you } \\
\text { even after you try to move him and talk to him, what to do? }\end{array}$} & Start CPR & $201(36.0 \%)$ & $210(35.7 \%)$ & \multirow{4}{*}{$\begin{array}{l}0.039 \\
S^{*}\end{array}$} \\
\hline & Activate EMS & $267(47.8 \%)$ & $283(48.0 \%)$ & \\
\hline & Put him in recovery position & 64(11.4\%) & $84(14.3 \%)$ & \\
\hline & Observe & $27(4.8 \%)$ & $12(2.0 \%)$ & \\
\hline
\end{tabular}




\section{Cureus}

If you do not want to give artificial respiration by direct contact with the mouth during CPR work, you can do the following:

If you and your friend are eating at the canteen and suddenly your friend is exposed to the symptoms of choking, what to do?

You are watching a child who suddenly started to choke while playing with him. I have made sure he is unable to cry or cough. What is your first response?

You see a person who does not respond drowned in the water. After getting out, he is breathing but does not respond. What is the first step?

\begin{tabular}{|c|c|c|c|}
\hline Mouth-mask ventilation and chest compression & $190(34.0 \%)$ & $209(35.5 \%)$ & \multirow{4}{*}{0.100} \\
\hline Chest compression only & 115(20.6\%) & $149(25.3 \%)$ & \\
\hline mask ventilation with chest compression & $106(19.0 \%)$ & $88(14.9 \%)$ & \\
\hline No CPR & $148(26.5 \%)$ & $143(24.3 \%)$ & \\
\hline Give abdominal thrusts & $203(36.3 \%)$ & $232(39.4 \%)$ & \multirow{4}{*}{0.153} \\
\hline Give chest compression & $118(21.1 \%)$ & $125(21.2 \%)$ & \\
\hline $\begin{array}{l}\text { Confirm foreign body aspiration by talking to } \\
\text { him }\end{array}$ & $68(12.2 \%)$ & $86(14.6 \%)$ & \\
\hline Give back blows & $170(30.4 \%)$ & $146(24.8 \%)$ & \\
\hline Start CPR immediately & $71(12.7 \%)$ & $51(8.7 \%)$ & \multirow{4}{*}{$\begin{array}{l}0.003 \\
S^{*}\end{array}$} \\
\hline $\begin{array}{l}\text { Try to remove the suspected foreign body by } \\
\text { blind finger sweeping technique }\end{array}$ & $175(31.3 \%)$ & $220(37.4 \%)$ & \\
\hline $\begin{array}{l}\text { Back blows and chest compression of five } \\
\text { cycles each then open the mouth and remove } \\
\text { foreign body only when it is seen }\end{array}$ & $273(48.8 \%)$ & $296(50.3 \%)$ & \\
\hline Give water to the infant & $40(7.2 \%)$ & $22(3.7 \%)$ & \\
\hline CPR for two minutes and inform EMS & $147(26.3 \%)$ & $150(25.5 \%)$ & \multirow{4}{*}{0.632} \\
\hline CPR for one minute and inform EMS & $108(19.3 \%)$ & $131(22.2 \%)$ & \\
\hline Compress the abdomen to remove the water & $242(43.3 \%)$ & $250(42.4 \%)$ & \\
\hline Keep him in the recovery position & $62(11.1 \%)$ & $58(9.8 \%)$ & \\
\hline Offer him some drinks, probably hypoglycemia & $141(25.2 \%)$ & $166(28.2 \%)$ & \multirow{4}{*}{$\begin{array}{l}0.003 \\
S^{*}\end{array}$} \\
\hline Possibly stroke, get him to the nearest clinic & $227(40.6 \%)$ & $272(46.2 \%)$ & \\
\hline $\begin{array}{l}\text { Possibly stroke, he may require thrombolysis } \\
\text { and hence activate emergency medical } \\
\text { services }\end{array}$ & $128(22.9 \%)$ & $116(19.7 \%)$ & \\
\hline $\begin{array}{l}\text { May be due to sleep deprivation, make him } \\
\text { sleep. }\end{array}$ & $63(11.3 \%)$ & $35(5.9 \%)$ & \\
\hline
\end{tabular}

You noticed that your colleague was not able to speak and he was exposed to weakness in the right upper limb. Which one of the following could be done?

\section{TABLE 6: Comparison between gender regarding practices for cardiopulmonary resuscitation} (CPR)

*Significant

EMS: emergency medical services

\section{Medical and non-medical comparison of knowledge and attitudes}

There was a significant increase among medical students rather than non-medical students $(\mathrm{p}<0.05)$ regarding knowledge and attitude for knowing the emergency telephone of Saudi Red Crescent (61.1\%), proper chest compression depth (44.2\%), and their thinking that a CPR training course is mandatory for all students as a graduation requirement (66.4\%). Their opinion regarding the best methods for increasing the awareness of the public about CPR was to inform people of the training courses currently available (42.9\%). They strongly agreed that a CPR training course is beneficial for students to life-save the public (78.6\%); 87.9\% of them wanted to learn CPR. But there is no significant difference between medical and non-medical students ( $\mathrm{p}>0.05$ ) regarding the right location for the application of chest compression and the chest compression rate (Table 7 ).

\section{Variables}

Do you know the emergency telephone
Yes 


\section{Cureus}

\begin{tabular}{|c|c|c|c|c|}
\hline number in Saudi Arabia "Red Crescent"? & No & $205(38.9 \%)$ & $310(49.9 \%)$ & $\mathrm{S}^{*}$ \\
\hline \multirow{4}{*}{ The abbreviation of BLS means? } & Best Life Support & $87(16.5 \%)$ & $160(25.8 \%)$ & \multirow{4}{*}{$\begin{array}{l}0.000 \\
S^{*}\end{array}$} \\
\hline & Basic Life Support & $249(47.2 \%)$ & $160(25.8 \%)$ & \\
\hline & Basic Lung Support & 105(19.9\%) & $172(27.7 \%)$ & \\
\hline & Basic Life Services & $86(16.3 \%)$ & $129(20.8 \%)$ & \\
\hline \multirow{4}{*}{$\begin{array}{l}\text { What is the survival rate in out-of-hospital cardiac arrest if CPR } \\
\text { is performed correctly? }\end{array}$} & $1 \%$ & $5(0.9 \%)$ & $25(4.0 \%)$ & \multirow{4}{*}{$\begin{array}{l}0.000 \\
\mathrm{~S}^{*}\end{array}$} \\
\hline & $25 \%$ & $70(13.3 \%)$ & $109(17.6 \%)$ & \\
\hline & $70 \%$ & $225(42.7 \%)$ & $269(43.3 \%)$ & \\
\hline & $95 \%$ & $227(43.1 \%)$ & $218(35.1 \%)$ & \\
\hline \multirow{4}{*}{ Where is the location of chest compression application? } & Left side of the chest & $92(17.5 \%)$ & $118(19.0 \%)$ & \multirow{4}{*}{0.147} \\
\hline & Right side of the chest & $24(4.6 \%)$ & $47(7.6 \%)$ & \\
\hline & Mid chest & $239(45.4 \%)$ & $267(43.0 \%)$ & \\
\hline & Xiphisternum & $172(32.6 \%)$ & 189(30.4\%) & \\
\hline \multirow{4}{*}{$\begin{array}{l}\text { What is the proper chest compression depth in CPR for adult } \\
\text { persons? }\end{array}$} & $2 \frac{1}{1} 2-3$ inches & $233(44.2 \%)$ & $235(37.8 \%)$ & \multirow{4}{*}{$\begin{array}{l}0.000 \\
\mathrm{~S}^{*}\end{array}$} \\
\hline & $1 \frac{1}{2}-2$ inches & $200(38.0 \%)$ & $217(34.9 \%)$ & \\
\hline & $1-1 \frac{11 / 2 \text { inches }}{}$ & $69(13.1 \%)$ & $101(16.3 \%)$ & \\
\hline & $1 / 2-1$ inch & $25(4.7 \%)$ & $68(11.0 \%)$ & \\
\hline \multirow{4}{*}{$\begin{array}{l}\text { What is the chest compression rate in CPR? For adult and child } \\
\text { persons? }\end{array}$} & $120 /$ mint. & $110(20.9 \%)$ & $141(22.7 \%)$ & \multirow{4}{*}{0.393} \\
\hline & 100/mint. & $138(26.2 \%)$ & $140(22.5 \%)$ & \\
\hline & 80/mint. & $120(22.8 \%)$ & $134(21.6 \%)$ & \\
\hline & 70/mint. & $159(30.2 \%)$ & $206(33.2 \%)$ & \\
\hline \multirow{4}{*}{$\begin{array}{l}\text { What is the chest compression rate in CPR? If you are the only } \\
\text { one to do that? }\end{array}$} & $30: 2$ & $161(30.6 \%)$ & $105(16.9 \%)$ & \multirow{4}{*}{$\begin{array}{l}0.000 \\
S^{*}\end{array}$} \\
\hline & 15:2 & $127(24.1 \%)$ & $193(31.1 \%)$ & \\
\hline & 15:1 & $69(13.1 \%)$ & $76(12.2 \%)$ & \\
\hline & $5: 1$ & $170(32.3 \%)$ & $247(39.8 \%)$ & \\
\hline \multirow{4}{*}{ Do you think CPR training courses should be: } & $\begin{array}{l}\text { Mandatory for all students } \\
\text { (graduation requirement) }\end{array}$ & $350(66.4 \%)$ & $285(45.9 \%)$ & \multirow{4}{*}{$\begin{array}{l}0.000 \\
S^{*}\end{array}$} \\
\hline & Mandatory for some majors & $96(18.2 \%)$ & $109(17.6 \%)$ & \\
\hline & Optional & $67(12.7 \%)$ & $202(32.5 \%)$ & \\
\hline & $\begin{array}{l}\text { Don't support the implementation } \\
\text { of training courses }\end{array}$ & $14(2.7 \%)$ & $25(4.0 \%)$ & \\
\hline \multirow{5}{*}{$\begin{array}{l}\text { What is the BEST method, in your opinion, to increase public } \\
\text { awareness of the importance of CPR? }\end{array}$} & Increased publicity & $222(42.1 \%)$ & $193(31.1 \%)$ & \multirow{5}{*}{$\begin{array}{l}0.000 \\
S^{*}\end{array}$} \\
\hline & $\begin{array}{l}\text { Inform people of the training } \\
\text { courses currently available }\end{array}$ & $226(42.9 \%)$ & $240(38.6 \%)$ & \\
\hline & Free training courses & $52(9.9 \%)$ & $124(20.0 \%)$ & \\
\hline & Increase the number of courses & $27(5.1 \%)$ & $53(8.5 \%)$ & \\
\hline & Others & $0(0.0 \%)$ & $11(1.8 \%)$ & \\
\hline \multirow[b]{3}{*}{$\begin{array}{l}\text { Do you think CPR training is beneficial for students for life- } \\
\text { saving the public? }\end{array}$} & Strongly agree & $414(78.6 \%)$ & $354(57.0 \%)$ & \multirow[b]{3}{*}{$\begin{array}{l}0.000 \\
\mathrm{~S}^{*}\end{array}$} \\
\hline & Agree & $84(15.9 \%)$ & $202(32.5 \%)$ & \\
\hline & Neutral & $25(4.7 \%)$ & $54(8.7 \%)$ & \\
\hline
\end{tabular}




\section{Cureus}

\begin{tabular}{|c|c|c|c|c|}
\hline & Disagree & $2(0.4 \%)$ & $6(1.0 \%)$ & \\
\hline & Strongly disagree & $2(0.4 \%)$ & $5(0.8 \%)$ & \\
\hline \multirow{2}{*}{ Have you ever taken a CPR training course? } & Yes & $125(23.7 \%)$ & 133(21.4\%) & \multirow{2}{*}{0.352} \\
\hline & No & 402(76.3\%) & 488(78.6\%) & \\
\hline \multirow{3}{*}{ What encouraged you to take the course? } & $\begin{array}{l}\text { Work or graduation requirement } \\
\text { (Mandatory) }\end{array}$ & 28(23.1\%) & $29(22.1 \%)$ & \multirow{3}{*}{0.683} \\
\hline & Personal benefit (Optional( & $87(71.9 \%)$ & $92(70.2 \%)$ & \\
\hline & $\begin{array}{l}\text { Previous experience proved the } \\
\text { importance of CPR }\end{array}$ & $6(5.0 \%)$ & $10(7.6 \%)$ & \\
\hline \multirow{2}{*}{ Do you want to learn CPR? } & Yes & $463(87.9 \%)$ & $484(77.9 \%)$ & \multirow{2}{*}{$\begin{array}{l}0.000 \\
\mathrm{~S}^{\star}\end{array}$} \\
\hline & No & $64(12.1 \%)$ & 137(22.1\%) & \\
\hline
\end{tabular}

TABLE 7: Comparison between medical and non-medical colleges regarding the knowledge and attitudes of cardiopulmonary resuscitation (CPR)

*Significant

\section{Medical and non-medical comparison of practices}

As regards the practice of $\mathrm{CPR}$ among medical and non-medical students. there is a significant increase among medical rather than than non-medical students $(p<0.05)$ regarding their first response if they saw a comatose person (36.8\%) and for giving abdominal thrusts if their friend was exposed to choking during eating (45.2\%), the activation of EMS and starting CPR for someone not responding to moving and talking, implementing back blows and chest compression of five cycles, opening the mouth and removing the foreign body on seeing a child who suddenly started to choke (58.1\%), and getting their colleagues to the nearest clinic if they not able to speak and were exposed to weakness in the right upper limb (51.8\%). But there is an increased significance of non-medical rather than medical students for compressing the abdomen to remove water if they saw any person drowning and not responding (46.2\%) (Table 8).

\begin{tabular}{|c|c|c|c|c|}
\hline \multicolumn{2}{|l|}{ Variables } & $\begin{array}{l}\text { Medical } \\
\mathrm{n}=527 \text { No } \\
\%\end{array}$ & $\begin{array}{l}\text { Non- } \\
\text { medical } n= \\
620 \text { No } \%\end{array}$ & $\begin{array}{l}\text { P- } \\
\text { value }\end{array}$ \\
\hline \multirow{4}{*}{ If you see someone comatose, what is your first response? } & Open airway & 194(36.8\%) & 215(34.6\%) & \multirow{4}{*}{$\begin{array}{l}0.001 \\
S^{*}\end{array}$} \\
\hline & Start chest compression & $53(10.1 \%)$ & 110(17.7\%) & \\
\hline & Look for safety & $264(50.1 \%)$ & $269(43.3 \%)$ & \\
\hline & Give two breathings & $16(3.0 \%)$ & $27(4.3 \%)$ & \\
\hline \multirow{4}{*}{$\begin{array}{l}\text { After making sure that someone does not respond to you } \\
\text { even after you try to move him and talk to him, what to do? }\end{array}$} & Start CPR & $211(40.0 \%)$ & $200(32.2 \%)$ & \multirow{4}{*}{$\begin{array}{l}0.000 \\
\mathrm{~S}^{*}\end{array}$} \\
\hline & Activate EMS & $248(47.1 \%)$ & $302(48.6 \%)$ & \\
\hline & Put him in the recovery position & $61(11.6 \%)$ & $87(14.0 \%)$ & \\
\hline & Observe & $7(1.3 \%)$ & $32(5.2 \%)$ & \\
\hline \multirow{4}{*}{$\begin{array}{l}\text { If you do not want to give artificial respiration by direct } \\
\text { contact with the mouth during CPR, you can do the } \\
\text { following: }\end{array}$} & Mouth-mask ventilation and chest compression & 169(32.1\%) & $230(37.0 \%)$ & \multirow{4}{*}{$\begin{array}{l}0.000 \\
S^{*}\end{array}$} \\
\hline & Chest compression only & 83(15.7\%) & $181(29.1 \%)$ & \\
\hline & mask ventilation with chest compression & $89(16.9 \%)$ & $105(16.9 \%)$ & \\
\hline & No CPR & $186(35.3 \%)$ & $105(16.9 \%)$ & \\
\hline \multirow{3}{*}{$\begin{array}{l}\text { If you and your friend are eating at the canteen and } \\
\text { suddenly your friend is exposed to the symptoms of } \\
\text { choking what to do }\end{array}$} & Give abdominal thrusts & $238(45.2 \%)$ & 197(31.7\%) & \multirow{3}{*}{0.000} \\
\hline & Give chest compression & $104(19.7 \%)$ & $139(22.4 \%)$ & \\
\hline & $\begin{array}{l}\text { Confirm foreign body aspiration by talking to } \\
\text { him }\end{array}$ & 83(15.7\%) & 71(11.4\%) & \\
\hline
\end{tabular}




\section{Cureus}

\begin{tabular}{|c|c|c|c|c|}
\hline & Give back blows & 102(19.4\%) & 214(34.5\%) & \\
\hline \multirow{4}{*}{$\begin{array}{l}\text { You are watching a child who suddenly started to choke } \\
\text { while playing with him. I have made sure he is unable to cry } \\
\text { or cough. What is your first response? }\end{array}$} & Start CPR immediately & $43(8.2 \%)$ & $79(12.7 \%)$ & \multirow{4}{*}{$\begin{array}{l}0.000 \\
S^{*}\end{array}$} \\
\hline & $\begin{array}{l}\text { Try to remove the suspected foreign body by } \\
\text { blind finger sweeping technique }\end{array}$ & 159(30.2\%) & $236(38.0 \%)$ & \\
\hline & $\begin{array}{l}\text { Back blows and chest compression of five } \\
\text { cycles each then open the mouth and remove } \\
\text { foreign body only when it is seen }\end{array}$ & $306(58.1 \%)$ & $263(42.4 \%)$ & \\
\hline & Give water to the infant & 19(3.6\%) & $43(6.9 \%)$ & \\
\hline \multirow{4}{*}{$\begin{array}{l}\text { You see a person who does not respond after drowning in } \\
\text { water. After taking him out, he is breathing but does not } \\
\text { respond. What is the first step? }\end{array}$} & CPR for two minutes and inform EMS & $167(31.7 \%)$ & $130(20.9 \%)$ & \multirow{4}{*}{$\begin{array}{l}0.001 \\
\mathrm{~S}^{\star}\end{array}$} \\
\hline & CPR for one minute and inform EMS & 105(19.9\%) & $134(21.6 \%)$ & \\
\hline & Compress the abdomen to remove the water & $205(38.9 \%)$ & $287(46.2 \%)$ & \\
\hline & Keep him in the recovery position & $50(9.5 \%)$ & $70(11.3 \%)$ & \\
\hline \multirow{4}{*}{$\begin{array}{l}\text { You noticed that your colleague was not able to speak and } \\
\text { he exposed to weakness in the right upper limb which one } \\
\text { of the following could be done }\end{array}$} & Offer him some drinks, probably hypoglycemia & 103(19.5\%) & $204(32.9 \%)$ & \multirow{4}{*}{$\begin{array}{l}0.000 \\
S^{*}\end{array}$} \\
\hline & Possibly stroke, get him to the nearest clinic & $273(51.8 \%)$ & $226(36.4 \%)$ & \\
\hline & $\begin{array}{l}\text { Possibly stroke, he may require thrombolysis } \\
\text { and hence activate emergency medical } \\
\text { services }\end{array}$ & $119(22.6 \%)$ & 125(20.1\%) & \\
\hline & $\begin{array}{l}\text { May be due to sleep deprivation, make him } \\
\text { sleep. }\end{array}$ & $32(6.1 \%)$ & $66(10.6 \%)$ & \\
\hline \multicolumn{5}{|c|}{$\begin{array}{l}\text { TABLE 8: Comparison between medical and non-medical colleges regarding practices for } \\
\text { cardiopulmonary resuscitation (CPR) }\end{array}$} \\
\hline \multicolumn{5}{|l|}{ *Significant } \\
\hline EMS: emergency medical services & & & & \\
\hline
\end{tabular}

\section{Discussion}

Cardiopulmonary resuscitation (CPR) is a lifesaving technique useful in many emergencies, including a heart attack or near drowning, in which someone's breathing or heartbeat has stopped. The American Heart Association recommends that everyone - untrained bystanders and medical personnel alike - begin CPR with chest compressions. It's far better to do something than to do nothing at all if you're fearful that your knowledge or abilities aren't 100\% complete. Remember, the difference between your doing something and doing nothing could be someone's life [6].

The current study aimed to assess the level of knowledge, attitudes, and practices regarding cardiopulmonary resuscitation among Qassim University students.

The present study finds that around half of students don't know the emergency telephone of Saudi Arabia Red Crescent (45\%). This is agreeing with another study conducted at Jouf University, which stated the same results. But it is less than another study conducted at King Saud University, which revealed that $70 \%$ of their students knew the Red Crescent telephone number [5,7].

On the other hand, this study showed that only $44 \%$ of students knew the right location of chest compression in CPR and this is in accordance with another study conducted at Qassim University, which revealed nearly the same results $(40.0 \%)[8]$.

Furthermore, this study showed that only ( $40.8 \%$ and $24.2 \%$, respectively) of students have insufficient knowledge regarding the proper chest compression depth in CPR and the chest compression rate for adults and children and this is due to the small number of training programs for CPR skills conducted at Qassim University. Also, there is no inclusion of a BLS course in the university curriculum for comparing with other students at King Saud University, which revealed sufficient knowledge $69 \%$ and 55\%, respectively. However, this result is nearly the same as another study conducted among secondary school students in Riyadh and has better knowledge than another study conducted at Qassim University in 2014 [8-10]. 
As regards the attitudes of students towards CPR, the majority of students in this study (55.5\%) think that the training program for CPR is mandatory for graduation, and it benefits them in saving the lives of people (66.9\%). These results are better than another study conducted on university students in Riyadh, 2008, which found that only $45 \%$ of their students believe that it is mandatory for graduation [5].

On the other hand, the majority of students in this study wanted to learn CPR (82.5\%), and this is a good, positive attitude among them. Also, this result is in accordance with another study conducted in New Zealand, which found nearly the same results (73.5\%) and with a study that was conducted in Riyadh, 2008, which showed better attitudes (90\%). These results reflect the importance of a CPR training program for university students and their benefit to them. The majority of students in our study think that the best way to increase the awareness of the public towards CPR is to inform them about the availability of training programs (40.1\%). These results disagree with another study conducted in Riyadh, which shows that about half of the students believe that the media such as television and social media is the best way to increase the awareness of people $[5,11]$.

Regarding the practice of students towards CPR, only $46.4 \%$ and $35.5 \%$ respectively, would look for safety and open airways in comatose persons. And this is insufficient practice for saving lives; this result is supported by another study conducted in 2014 at Qassim University, which revealed that the first practice for a comatose person is to look for safety and then an open airway. Furthermore, our study stated that the majority of students (47.9\%) would activate EMS if they saw someone does not respond to moving or talking, and these results are in accordance with the same study conducted in 2014 [8].

On the other hand, this study stated that only $37.9 \%$ of participants would give abdominal thrusts to their friends if they are exposed to choking during eating. This is less than in another study conducted in 2010, which shows a higher level of practice (54.1\%). Also, the present study finds that $50 \%$ of students will do back blows and chest compressions of five cycles, open the mouth, and remove the foreign body if they are watching a child who suddenly started to choke, and about $42.9 \%$ of the participants will compress the abdomen to remove water in a drowned person. This is in accordance with another study done in 2015 at an Ethiopian university. Furthermore, the current study shows that about $43.5 \%$ of students will take their colleagues to the nearest clinic if they were not able to speak and exposed to weakness in the right upper limb, and this indicates that they have good practice in this situation for saving the lives of their colleagues [12-13].

In spite of these results, the current study revealed that there is a significant increase of knowledge and attitudes regarding CPR among females rather than males in the majority of items and no significant difference between them in most practices. This indicates that the awareness of female students is better than that of males and similar results were find in other studies conducted in 2014 at an Ethiopian university and in 2015 in Hong Kong [13-14]. On the other hand, the present study shows that there are significant increases of knowledge, attitudes, and practices regarding CPR among medical students rather than non-medical students at Qassim University, and this is because their college curriculums will help them and increase their awareness regarding CPR, and there are no other studies done to support this results $[13-14]$.

\section{Conclusions}

Based on our study, the knowledge, attitudes, and practices of Qassim University students related to CPR are insufficient and need to be improved. Also, medical students are better than non-medical students and females are better at CPR than males so we recommend the incorporation of a BLS course, including CPR learning procedures, in the university curriculum, with regular reassessments, would increase the knowledge and application of CPR skills among students to save people lives.

\section{Additional Information}

\section{Disclosures}

Human subjects: Consent was obtained by all participants in this study. Deanship of Scientific Research, Qassim University, Saudi Arabia issued approval 20180305. From: Subcommittee of Health Research Ethics, Deanship of Scientific Research, Qassim University. Research title:" Knowledge, attitudes and practices of Qassim University's students towards Cardiopulmonary Resuscitation, Saudi Arabia" Dear P.I., We are pleased to inform you that the subcommittee of Health Research Ethics had approved your research proposal. Upon receiving this approval, you may commence your fieldwork at your convenience. Animal subjects: All authors have confirmed that this study did not involve animal subjects or tissue. Conflicts of interest: In compliance with the ICMJE uniform disclosure form, all authors declare the following: Payment/services info: All authors have declared that no financial support was received from any organization for the submitted work. Financial relationships: All authors have declared that they have no financial relationships at present or within the previous three years with any organizations that might have an interest in the submitted work. Other relationships: All authors have declared that there are no other relationships or activities that could appear to have influenced the submitted work. 


\section{References}

1. Hung MS, Chow MC, Chu TT, Wong PP, Nam WY, Ki VL, Chan CT: College students' knowledge and attitudes toward bystander cardiopulmonary resuscitation: a cross-sectional survey. Cogent Med. 2017, 4:1334408. DOI:10.1080/2331205X.2017.1334408

2. Ringold S, Glass TJ, Glass RM: Cardiopulmonary resuscitation (CPR). JAMA. 2005, 293:388. 10.1001/jama.293.3.388

3. Adabag AS, Luepker RV, Roger VL, Gersh BJ: Sudden cardiac death: epidemiology and risk factors. Nat Rev Cardiol. 2010, 7:216-225. 10.1038/nrcardio.2010.3

4. Parnell MM, Pearson J, Galletly DC, Larsen PD: Knowledge of and attitudes towards resuscitation in New Zealand high-school students. Emerg Med J. 2006, 23:899-902. 10.1136/emj.2006.041160

5. Al-Turki YA, Al-Fraih YS, Jalaly JB, et al.: Knowledge and attitudes towards cardiopulmonary resuscitation among university students in Riyadh. Saudi Med J. 2008, 29:1306-1309.

6. Cardiopulmonary resuscitation (CPR): first aid . (2018). https://www.mayoclinic.org/first-aid/first-aidcpr/basics/art-20056600.

7. Alsharari AO, Alduraywish A, Al-Zarea EA, Salmon NI, Sheikh MS: Current status of knowledge about cardiopulmonary resuscitation among the university students in the northern region of Saudi Arabia. Cardiol Res Pract. 2018, 2018:3687472. 10.1155/2018/3687472

8. Almesned A, Almeman A, Alakhtar AM, AlAboudi AA, Alotaibi AZ, Al-Ghasham YA, Aldamegh MS: Basic life support knowledge of healthcare students and professionals in the Qassim University. Int J Health Sci (Oassim). 2014, 8:141-150.

9. Alotaibi O, Alamri F, Almufleh L, Alsougi W: Basic life support: knowledge and attitude among dental students and staff in the college of dentistry, King Saud University. Saudi J Dent Res. 2016, 7:51-56.

10. Alanazi A, Hotan B, Alqahtani M, ALhalyabah H, Alanazi A, Al-oraibi S: Community awareness about cardiopulmonary resuscitation among secondary school students in Riyadh. World J Med Sci. 2013, 8:186189.

11. Larsen P, Pearson J, Galletly D: Knowledge and attitudes towards cardiopulmonary resuscitation in the community. N Z Med J. 2004, 117:870.

12. Chandrasekaran S, Kumar S, Bhat SA, Saravanakumar, Shabbir PM, Chandrasekaran VP: Awareness of basic life support among medical, dental, nursing students and doctors. Indian J Anaesth. 2010, 54:121-126. 10.4103/0019-5049.63650

13. Tsegaye W, Tesfaye M, Alemu M: Knowledge, attitude and practice of cardiopulmonary resuscitation and associated factors in Ethiopian university medical students. J Gen Pract. 2015, 3:206. 10.4172/23299126.1000206

14. Chair SY, Hung MS, Lui JC, Lee DT, Shiu IY, Choi KC: Public knowledge and attitudes towards cardiopulmonary resuscitation in Hong Kong: telephone survey. Hong Kong Med J. 2014, 20:126-133. 